\title{
Zooplankton of Mokraya Sura river
}

\author{
Yakovenko Vladymir ${ }^{1}$, Fedonenko Elena ${ }^{1}$. \\ ${ }^{1}$ Oles Honchar Dnipropetrovsk National University, Ukraine
}

\begin{abstract}
Facultyof Biology, Ecology and Medicine, Departmentof General Biology and Water Bioresources
P.M.B. 49050, Dnepropetrovsk, Ukraine
\end{abstract}

Corresponding Email: yakovenko@mail.ru

Keywords: saprobionts, rotifers, sewage, eutrophication, small rivers, filter-feeding crustaceans.

\begin{abstract}
Structural and functional characteristics of zooplankton as well as the results of biotesting were researched to indicate the ecological status of Mokraya Sura river sites. Zooplankton sampling was performed at the sites of Mokraya Sura river in autumn 2014 and in spring 2015. Species composition and abundance of zooplankton showed that zooplankton is most depressed at the upper sites of the river due to joint effect of slime accumulation eutrophication and industrial sewage. Biotesting results estimated water quality of the site near aeration plant sewage emergency discharge as most polluted of the river sites where large abundance and biomass of zooplankton were created mostly by planktonic rotifers. Large figures of filter-seeding crustaceans as well as low saprobity index indicate improvement in water quality at the sites $3 \mathrm{~km}$ and $2 \mathrm{~km}$ upstream from the river mouth.
\end{abstract}

\section{INTRODUCTION}

For the first time zooplankton of Mokraya Sura river was described in the 30 s of the twentieth century as more productive compared with reservoir zooplankton [15]. Later domestic and industrial wastewater impact caused zooplankton species reduction in Mokraya Sura river and rotifers became the dominant grope in zooplankton community of the river $[4,16]$. Mokraya Sura river is one of Zaporozhskoye reservoir tributaries and this river receives a significant number of domestic and industrial sewage. Eutrophication is the main ecological problem of Mokraya Sura river because of agricultural and domestic wastewaters as well as aeration plant sewage emergency discharge into the river. High concentration of organic matter and shore cutting together with macrophytes overgrowing [1] and slime accumulation in Mokraya Shura river lead to shallowing and ending of the river. Similar problems concerning small rivers are noted in numerous works of scientists $[6,9,10,12]$. Industrial sewage of tyre and tube-rolling plants also flow into the river. Toxic compounds such as heavy metals, oil products and surface-active compounds flowing into the river inhibit hydrobionts reproduction. Sewage impact together with slime accumulation causes transformation of the river hydrobiocenosis. Thus an urgent task is to estimate the current ecological state and water quality of Mokraya Shura sites that's why studying of such a sensitive component as zooplankton supported by the results of biotesting is very important to improve ecology of the river.

\section{MATERIALS AND METHODS}

To study zooplankton of Mokraya Sura river samples of zooplankton were taken taken from 15 to 17 September 2014 and from 12 to 14 May 2015. Zooplankton distribution along the river was studied in the six sites: 1) Near the tire plant, 2) Near the Dnepropetrovsk - Zaporozhye highway, 3) Near the pontoon bridge, 4) $3 \mathrm{~km}$ upstream from the river mouth, 5) $2 \mathrm{~km}$ upstream from the river mouth, 6) mouth of Mokraya Sura river. At each site the samples were taken at the triple replication. Planktonic mesh sieve № 73 was used to take samples of zooplankton according to standard methods [17] from 50 to 100 liters of reservoir water was filtered through. Sampled material was fixated in $4 \%$ solution of formaldehyde and settled in graduated cylinder. Qualitative 
and quantitative investigation of the material sampled was carried out in the laboratory using binocular microscope MBS-2 and microscope MBI-2 in Bogorova cell [7]. Samples for biotesting were taken from 12 to 14 May 2015 and biotesting of water from the river sites was performed using the recommendations [8]. Water quality of the river sites was estimatied was in accordance with the recommendations [18]. Significance of differences as mean-square deviation, corre were performed using the Mstat and Excel programs for Windows.

\section{RESULTS AND DISCUSSIONS}

During the investigated period among the sites of Mokraya Sura river the lowest number of species has been registered at the upper sites: «Near the tire plant» and «Near the Dnepropetrovsk Zaporozhye highway» (fig. 1). At these sites the rotifers Rotaria rotatoria, $R$. neptunia, Adineta gracillis, Philodina roseola, Harbotrocha sp. from the class Bdelloidea dominated.

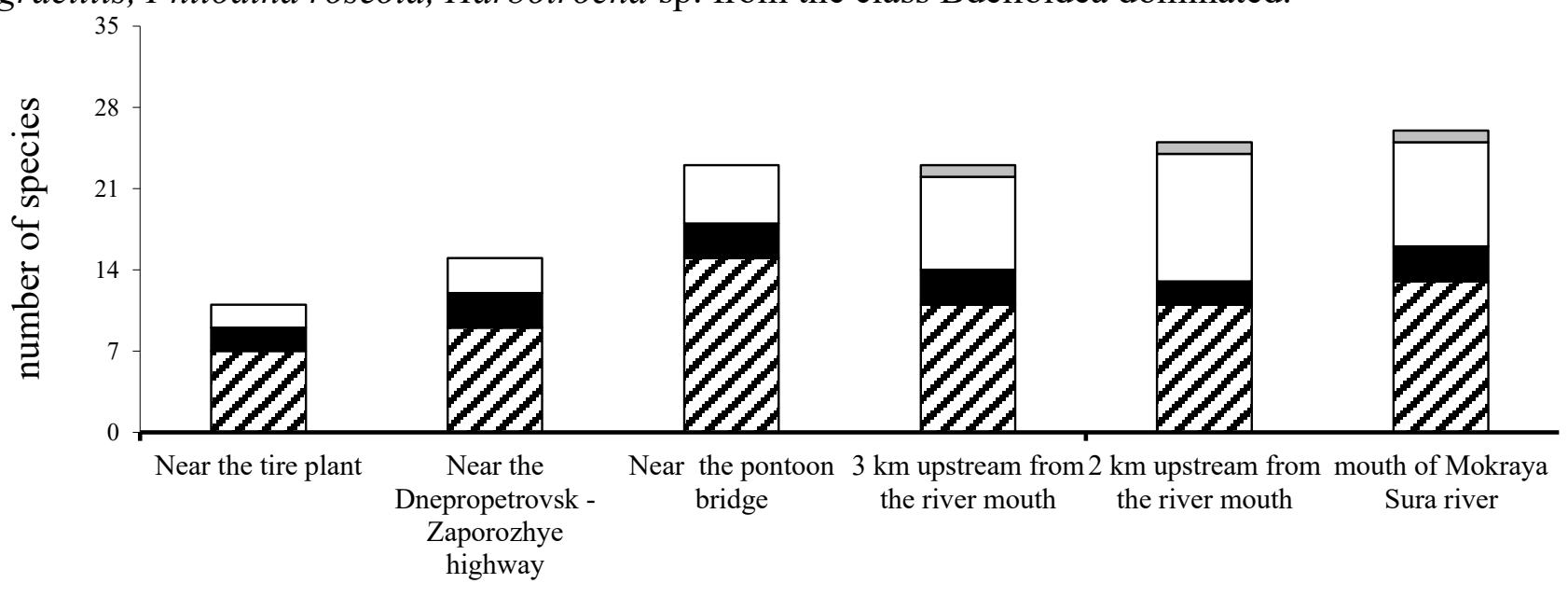

Rotatoria $\quad$ Copepoda $\quad \square$ Cladocera $\quad \square$ Veligers of dreissena

Fig.1. Number of zooplankton species at the sites of Mokraya Sura river in autumn and spring.

Proportion of these species of total zooplankton species was $61 \%$ in autumn and $63 \%$ in spring. Species number of demersal bdelloid rotifers was numerous while filter-feeding crustaceans were absent in water column. Dominance of bdelloid rotifers was caused by slime accumulation at the upper sites of the river. Depth of the river at these sites was no more than $0.5 \mathrm{~m}$. Bdelloid rotifers are resistant not only to suspended solids but they can also withstand impact of heavy metals and other toxic agents of river industrial sewage [3, 5, 11, 14]. Filter-feeding crustaceans usually die under such conditions because their filtration apparatus quickly becomes clogged and also these crustaceans are sensitive to toxic agents $[2,13]$.

Near the pontoon bridge number of bdelloid rotifers species decreased greatly to $12 \%$ of the total species number in comparison with the upper sites of the river. On the other hand an increasing of species diversity of planktonic saprobiotic rotifers such as Brachionus calyciflorus, Br. diversicornis, Br. quadridentatus, Asplanchna priodonta, A. brightwelli, Synchaeta pectinata, Anuraeopsis fissa, Filinia longiseta, F. mayor has been observed. At this site emergency discharge of aeration plant sewage occur and increasing of species diversity of planktonic saprobiotic rotifers is an indicator of river water pollution with organic matter.

At the sites $3 \mathrm{~km}$ and $2 \mathrm{~km}$ upstream from the river mouth the total species number reduced but species diversity of filter-feeding crustaceans was highest compared with other investigated sites. At the river mouth species diversity of planktonic rotifers increased slightly. Outlet of the tube with purifed wastewaters from aeration plant is situated here that causing reproduction of planktonic rotifers species. Mixing of reservoir and river waters also caused increasing of zooplankton total species number.

In autumn abundance and biomass of zooplankton reached the highest values near the pontoon bridge and in the river mouth while these figures were the lowest at the upper sites where 
bdelloid rotifers percentage of total zooplankton abundance reached $97 \%$ (fig. 2). Near the pontoon bridge zooplankton abundance increased to 136,4 thous. ind $/ \mathrm{m}^{3}$, due to planktonic rotifers reproduction. Eutrofication effect due aeration plant sewage emergency discharge caused reproduction of rotifers - saprobionts near the pontoon bridge. Thus planktonic species dominated at the sites where abundance of zooplankton was maximal while bottom species dominated at the upper sites where abundance of zooplankton was minimal. Significant numbers of dreissena veligers entering from the reservoir is a specific feature of Mokraya Sura mouth where river and reservoir waters mix.

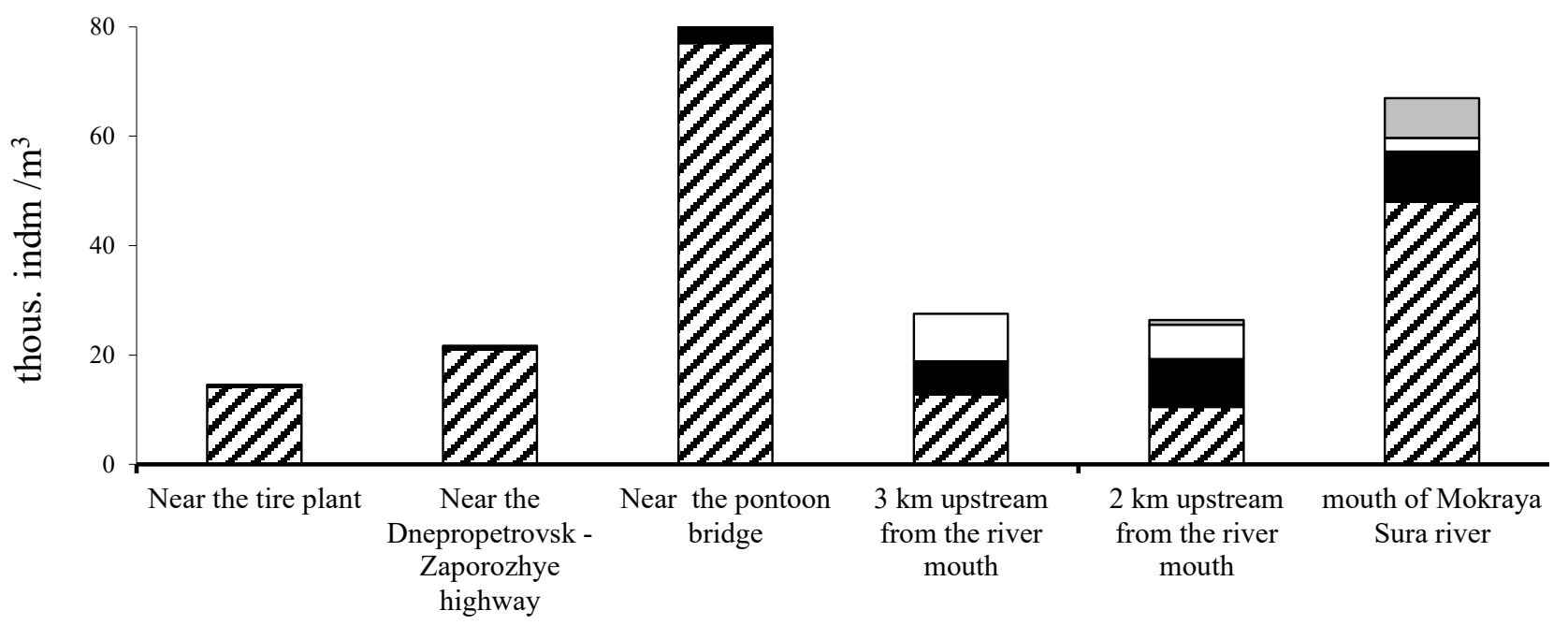

\begin{tabular}{|lll}
\hline Rotatoria $\quad \square$ Copepoda $\quad \square$ Cladocera $\quad \square$ Veligers of dreissena \\
\hline
\end{tabular}

Fig. 2. Abundance of zooplankton at the sites of Mokraya Sura river in autumn.

Among the investigated sites biomass of zooplankton varied to a greater extent compared with zooplankton abundance (fig. 3). Rotifers dominated at the upper sites while abundance of crustaceans increased at the sites situated not far from the river mouth. Low zooplankton abundance together with low individual mass of rotifers caused the smallest biomass of zooplankton at the upper sites of Mokraya Sura river. At the sites $3 \mathrm{~km}$ and $2 \mathrm{~km}$ upstream from the river mouth such cladocerans species as Chydorus sphaericus, Bosmina longirostris, Podonevadne trigona dominated especially by biomass of zooplankton. At these sites situated not far from the river mouth percentage of filter-feeding crustaceans abundance as well and biomass was highest compared with other investigated sites at 5\% significance level. Large figures of Cladocera development indicates improvement of water quality at these sites.

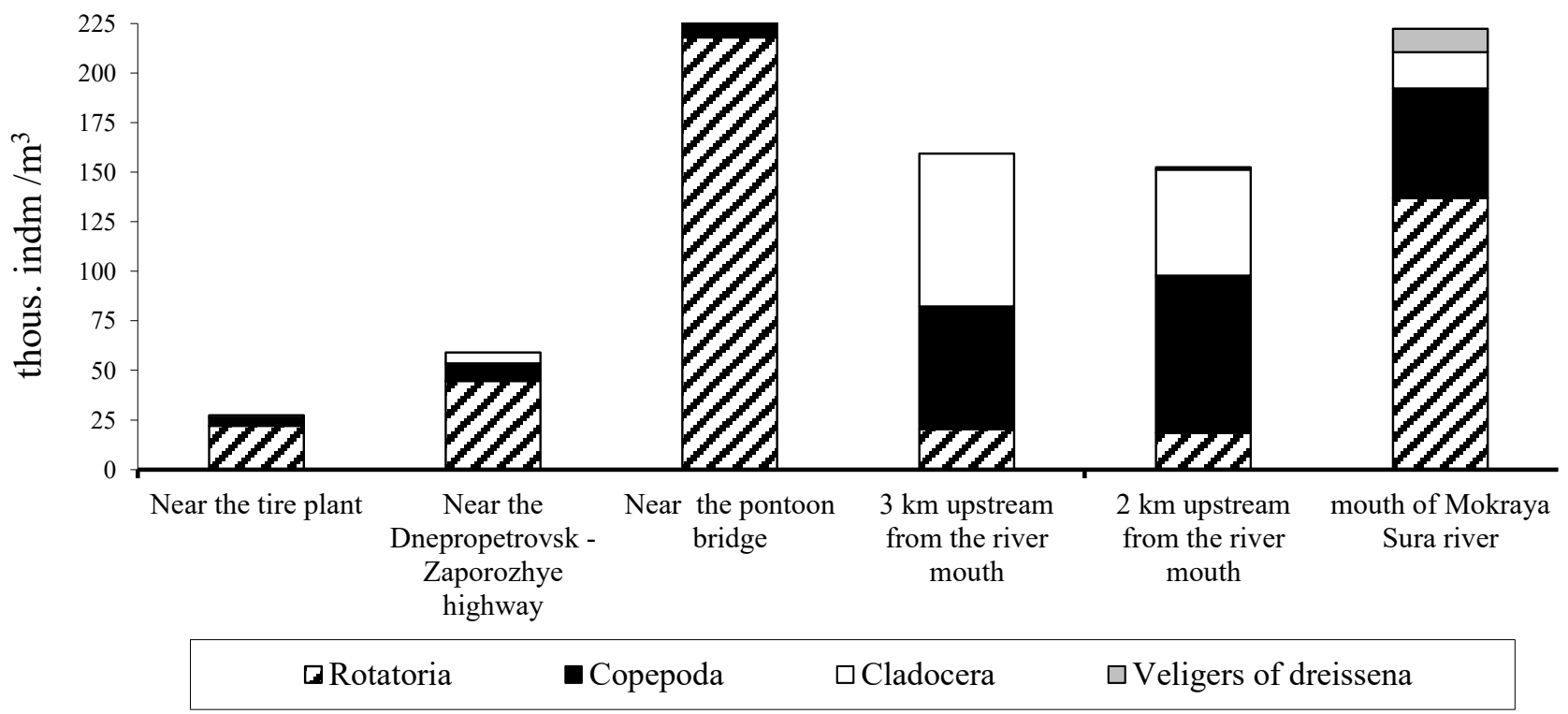

Fig. 3. Biomass of zooplankton at the sites of Mokraya Sura river in autumn 
In spring abundance and biomass of zooplankton varied slightly compared with autumn at all river sites except the site near the pontoon bridge and at the river mouth. Under low temperature crustaceans abundance was minimal and rotifers dominated (fig. 4). Near the Dnepropetrovsk Zaporozhye highway abundance of zooplankton was even higher in comparison with the sites $3 \mathrm{~km}$ and $2 \mathrm{~km}$ upstream from the river mouth. Highest figures of zooplankton abundance and biomass near the pontoon bridge was caused due to sewage discharge and high concentration of organic matter stimulates reproduction of planktonic rotifers - saprobionts in spite of spring low temperature (from 10 to $12^{\circ} \mathrm{C}$ ). Near the tire plant abundance of zooplankton was the lowest due to simultaneous impact of slime accumulation and industrial sewage pollution.

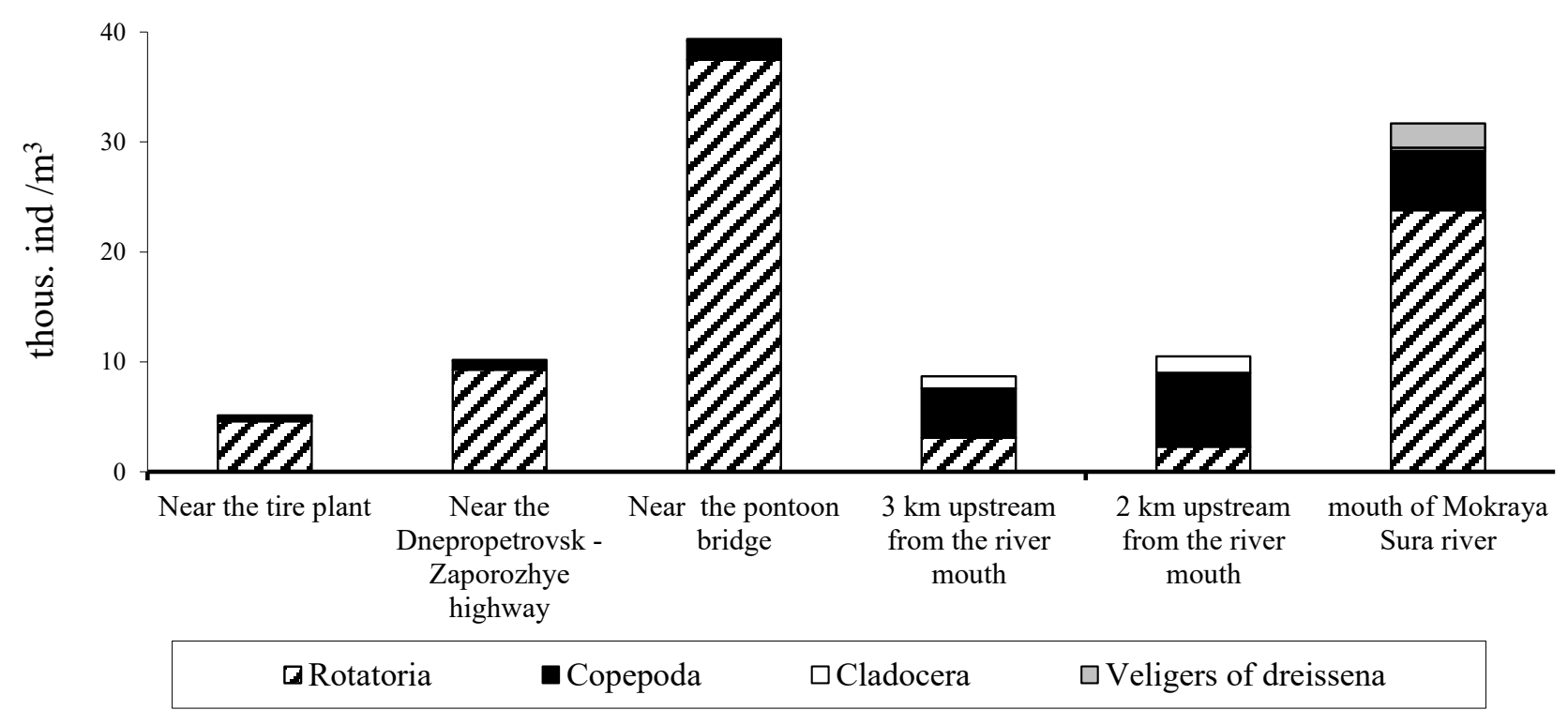

Fig. 4. Abundance of zooplankton at the sites of Mokraya Sura river in spring.

At the upper sites of the river: «Near the tire plant» and «Near the Dnepropetrovsk Zaporozhye highway» saproboty index was maximal, with highest figures in spring - up to 2.84 (fig. 5), that corresponds to the category of water quality "Dirty» according to the classification [18].

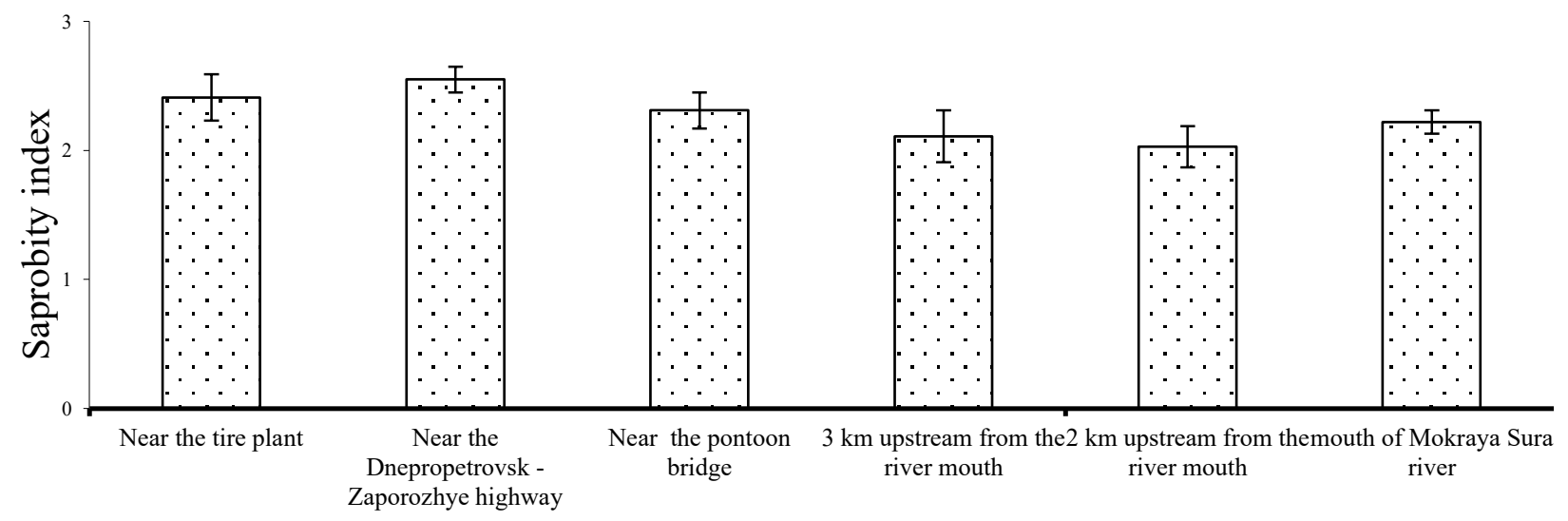




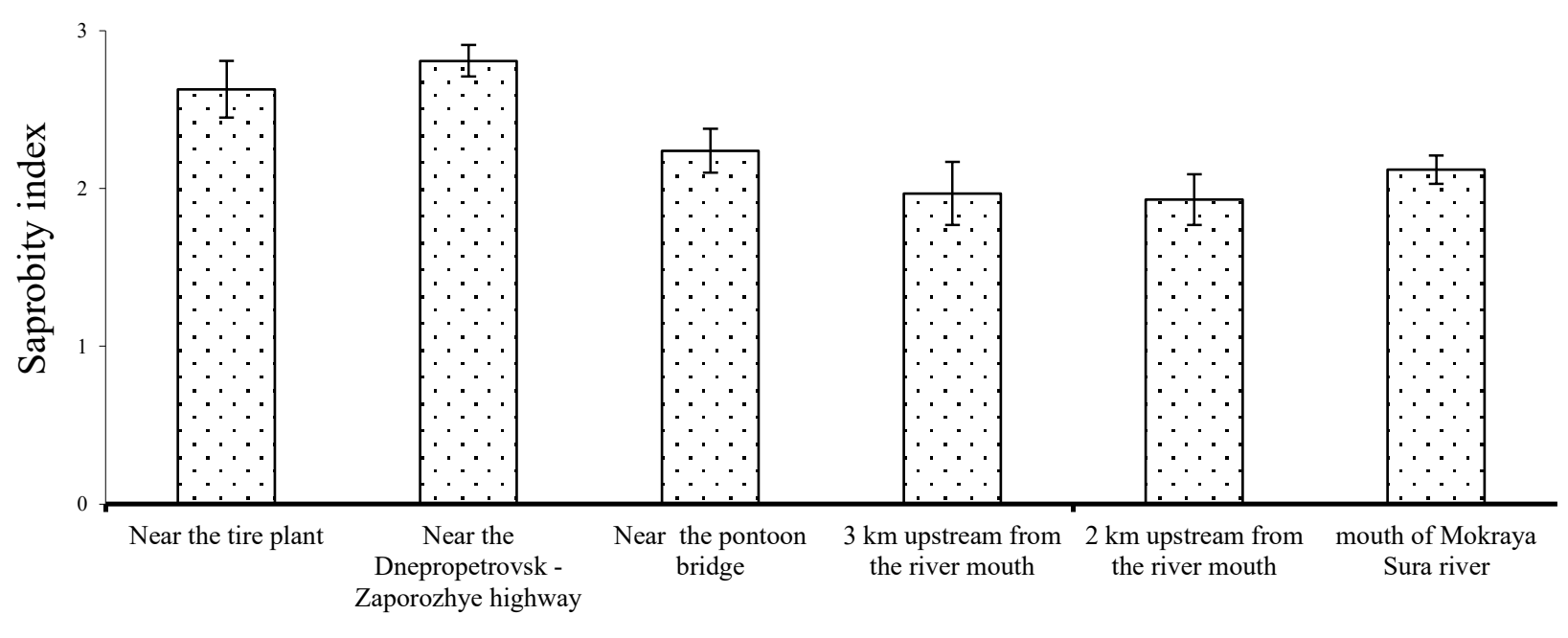

$\mathrm{B}$

Fig. 5. Saprobity index of zooplankton at the sites of Mokraya Sura river in autumn (A) and in spring (B).

High value of the index was caused by benthic species of bdelloid rotifers. Near the pontoon bridge where aeration plant sewage discharges into the river saprobity index value corresponded to water quality class «Polluted» due to large number of planktonic rotifers - saprobionts species and their high abundance. In the river mouth with outlet of the tube from aeration plant saprobity index value decreased compared with the site of sewage emergency discharge and water corresponded to quality class «Contaminated». Water quality corresponded to the category «Moderately polluted». Decreasing of the index in the river mouth is caused by two reasons: 1) Sewage from aeration plant arising out of the tube is purified, 2) Water arising out of the tube is diluted with not only river but also with reservoir water. The lowest values of saprobity index was recorded at the sites $3 \mathrm{~km}$ and 2 $\mathrm{km}$ upstream from the river mouth, where the water quality corresponded to the category «Relatively clean».

The results of biotesting showed the maximum toxicity of water in the river at the site «Near the pontoon bridge». Percantage of animals Daphnia magna Strauss who died within 4 days in water from this site averaged $53.7 \%$ (fig. 6). This percentage corresponds to the category of quality «Polluted», that confirms the data of zooplankton samples.

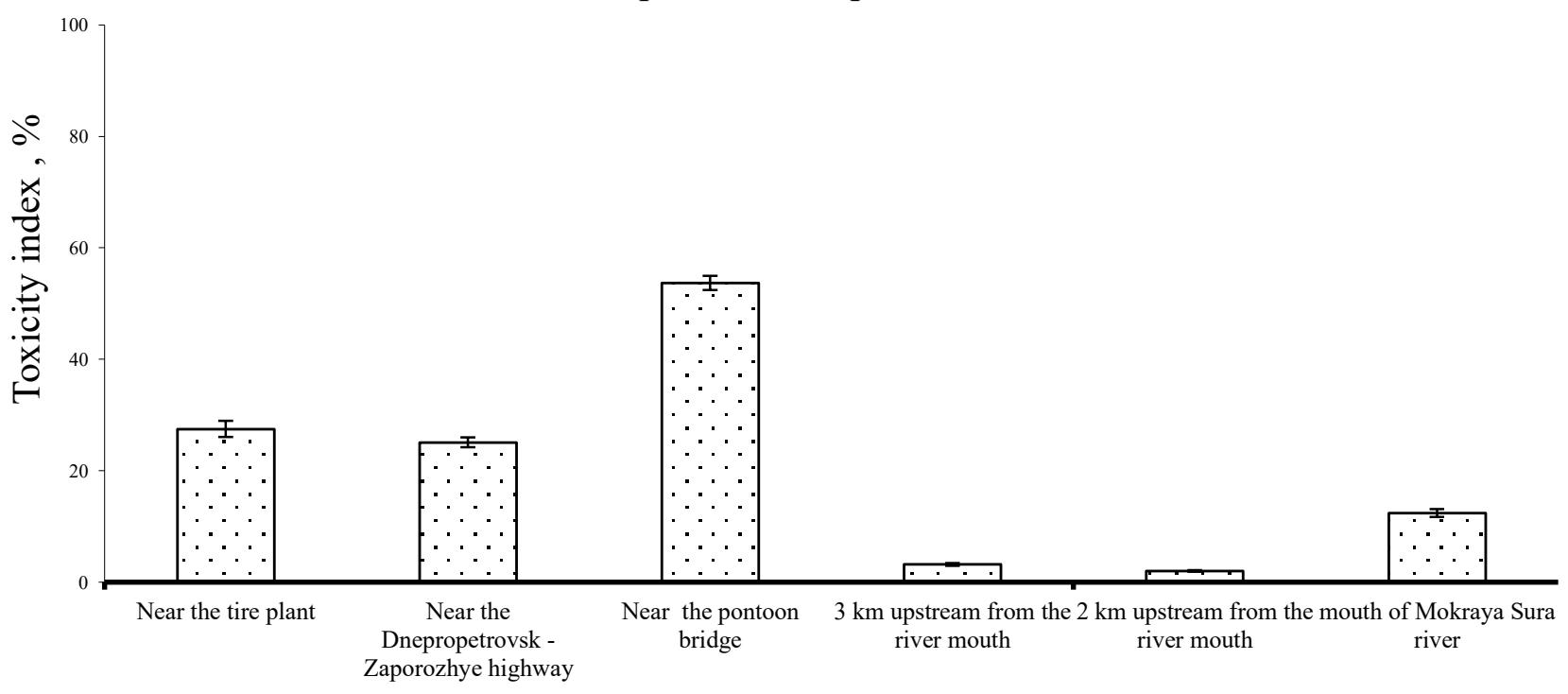

Fig. 6. Toxicity index of zooplankton at the sites of Mokraya Sura river in spring. 
At the sites «Near the tire plant» and «Near the Dnepropetrovsk - Zaporozhye highway» percentage of daphnia who died within 4 days (toxicity index) in water from this site averaged 25.1 $-27.5 \%$ that corresponds to the category of quality «Moderately polluted» quality. Taking into account high saprobity index water quality of this site should be characterized as «Polluted». Thus biotesting results don't correspond with zooplankton samples which indicated the upper sites as the most contaminated. This may be due to deposition of toxic agents into slime under low depth at the upper sites of the river. Water quality of other sites estimated on biotesting and zooplankton samples results corresponded. Thus in the river mouth $12.4 \%$ of daphnia died that corresponded to the water quality «Moderately polluted». In water from the sites $3 \mathrm{~km}$ and $2 \mathrm{~km}$ upstream from the river mouth almost all daphnia survived within 4 days that allows to estimate water quality of these sites as «Clean».

\section{CONCLUSION}

It was found that the lowest abundance and biomass of zooplankton was at the upper sites of Mokraya Sura river due to joint effect of slime accumulation eutrophication and industrial sewage. Bdelloid rotifers dominance lead to high saprobity index and indicates eutrophication effect here. At other sites of the river planktonic rotifers - saprobionts indicates the eutrophication effect which was maximal at the site of aeration plant sewage emergency discharge. Degree of planktonic rotifers dominance corresponded to degree of zooplankton abundance while bottom rotifers dominated at the sites where abundance of zooplankton was minimal. Large figures of filter-seeding crustaceans as well as low saprobity index indicate improvement in water quality at the sites $3 \mathrm{~km}$ and $2 \mathrm{~km}$ upstream from the river mouth. The results of zooplankton samples and biotesting corresponded except the upper sites of the river where toxicity was lower in comparison with the site of aeration plant that may be due to deposition of toxic agents into slime under low depth.

\section{References}

[1] B. Baranovskiy (2000). Macrophytes of the channel plain reservoirs, Dnepropetrovsk, 172p.

[2] E. Biesinger G. Christensen (1972). Effects of various metals on survival, growth, reproduction, and metabolism of Daphrria magna J. Fish. Res.Board Canada, Vol. 29, pp. 1691 - 1700.

[3] R. Claudia, P. Elena (1979). Life tables of Philodina roseola (Rotifera) under conditions of chronic cadmium and zinc stress, Bolletino di zoologia, Vol. 46 (3), pp. 209-216

[4] A. Dyha, V. Rubanenko (1977). Dynamics of zooplankton of Zaporozskoe reservoir bays under the eutrophication process, Circulation of matter and energy in water bodies, Listvennichnoe on Lake Baikal, pp. 166-169.

[5] E. Gladyshev M. Meselson (2008). Extreme resistance of bdelloid rotifers to ionizing radiation, Proc Natl Acad Sci U S A, Vol. 105(13), pp. 5139-5144.

[6] I. Grib, A. Merezhko (1991). The main directions of the strategy to protect and restore the ecosystems of small rivers, II All-Union Conference on fisheries toxicology, Vol. 1., St. Petersburg, pp. $135-136$.

[7] I. Kiselev (1956). Methods of Plankton Study, in the Life of Fresh Waters, Moscow, Vol. 4 (1), pp. 183-265.

[8] I. Konovets, L. Kinnis (2006). Biotesting of surface water bodies and bottom deposits by using of Cladocers, in Methods of of surface waterbodies hydroecological studies, edited by. V. D Romanenko, Kiev, pp. 340 - 365.

[9] A. Krylov (1996). The Zooplankton of Small Rivers under Different Anthropogenic Loads, Abstract of Cand. Sci. (Biol.) Dissertation, Borok. 
[10] A. Krylov (1993). The Zooplankton and Water Quality in a Small River Exposed to the Effect of Industrial Wastewater Discharge, in Zoocenoses of Water Bodies in the Upper Volga Basin under Conditions of Anthropogenic Influence, Vol. 69 (72), pp. 39-48.

[11] L. Kutikova (2005). Bdelloid rotifers of Russia fauna // Proceedings of the Zoological Institute RAS. Vol. 305, Moscow. KMK Scientific Press Ltd., 315 p.

[12] A. Merezhko (1987). Ecological problems of small rivers exploitation, Hydrobiological journal, Vol. 23 (1), pp. $3-7$.

[13] D. Nielsen, G. Watson (2008). The response of epibenthic rotifers and microcrustacean communities to flow manipulations in lowland rivers, Hydrobiologia, Vol. 603, pp. 117-128

[14] C. Ricci (1987) Ecology of bdelloids: How to be successful. Hydrobiologia, Vol. 147, pp. 117-127.

[15] S. Rozhko-Rozhkevich (1937). Zooplankton of tributaries and baulks of stepped Dnipro part and transformations of zooplankton under impact of Dnipro hydro-electric power station // Bulletin of Dnipropetrovsk hydrobiological station, Dniepropetrovsk. Vol. 2, pp. 85 - 104.

[16] V. Yakovenko (2009) Zooplankton of the Dnieper reservoir under conditions of anthropogenic pressure : Abstract of Cand. Sci. (Biol.) Dissertation, Kiev.

[17] V. Zhadin (1960). Methods of hydroecological study, Higher School, Moscow.

[18] V. Zhukinskyy (2006). Methods of complex ecological estimation of surface water bodies quality, in Methods of of surface waterbodies hydroecological studies, edited by. V. D Romanenko, Kiev, pp. $379-401$. 